\title{
Kontroversi Islam Revisionis : David S. Powers, Zayd Ibn Ḥārithah dan Tertutupnya Pintu Kenabian
}

\author{
Oleh: Mu'ammar Zayn Qadafy
}

Email: uammar.zayn.qadafy@orient.uni-freiburg.de Albert-Ludwig Universitat, Freiburg, Jerman

\begin{abstract}
Abstrak
Artikel ini mendeskripsikan kontroversi buku David S. Powers yang berjudul "Muhammad is Not the Father of Any of Your Men: The Making of The Last Prophet", salah satu masterpiece dari seorang akademisi yang ingin merevisi sejarah Islam dari versi yang biasa dipahami umat Islam. Buku ini juga menjadi salah satu karya revisionis yang mendapatkan paling banyak atensi berupa pujian sekaligus kritik. Review-review atas buku Powers tersebut juga dijadikan referensi utama dalam artikel ini.

Dengan menguraikan dasar argumentasi Power beserta tanggapan para pemerhati sejarah Islam awal, artikel ini ingin menunjukkan bahwa dalam asumsinya yang paling mendasar sekalipun, karya Powers -dan karya revisionis lain- memiliki kelemahan metodologis: (1) asumsi dasar Powers tentang "genealogi kenabian" dan "doktrin tertutupnya pintu kenabian dalam Islam" muncul dari keyakinannya tentang adanya pola khas yang sama di antara agama-agama samawi. Usahanya untuk menemukan pola khas ini menjadikan Power apatis terhadap reliabilitas sumber Islam tradisional dan secara membabi buta menganggap semuanya fiksi dan fabula; (2) Percobaan intertekstualisasi yang dilakukan Powers terlalu absurd
\end{abstract}


dan tidak apple to apple karena menggunakan dokumen sejarah di millennium kedua sebelum masehi untuk membaca sejarah di abad ke-7 Masehi; (3) rekonstruksi kodikologis Powers terhadap kata kallah vis a vis kalālah gagal menjelaskan logika kebahasaan di balik amnesia leksikografik massal terhadap kata pertama dan muncul dengan tiba-tibanya kata kedua. Powers juga mengenyampingkan temuan lain bahwa kata kalālah sudah dipakai sejak zaman PraIslam dan bahwa perbaikan manuskrip al-Qur'an yang ia temukan semata-mata hanyalah sejenis haplografi saja.

Kata Kunci : Islam Revisionis, David S. Powers, Khätam al-Nabiyyīn

\section{PENDAHULUAN}

Kemunculan dua buku Mun'im Sirry tentang Islam Revisionis menandai dimulainya kajian terhadap sejarah Islam formatif di belantika studi Qur'an di Indonesia. Masih terlalu dini untuk menilai berhasil atau tidaknya dua karya monumental tersebut merangsang nalar kritis umat Islam di Indonesia tentang sejarah agama dan kitab suci mereka sebagaimana yang diinginkan penulisnya. ${ }^{1}$ Meski demikian, sudah semestinya pantikan dari Sirry direspon secara serius mengingat tema besar sejarah Islam formatif yang diusungnya adalah sesuatu yang krusial dalam keberagamaan umat Islam.

Dalam buku pertama, Sirry menunjukkan moderasinya dengan menawarkan jalan tengah terhadap perdebatan kedua belah pihak. Mengakomodir kritik revisionis terhadap sikap umat Islam yang sering menerima versi sejarah dari sumber tradisional apa adanya, Sirry berkesimpulan bahwa 'berbagai narasi tradisional tentang Islam awal lebih dimaksudkan untuk memvalidasi doktrin yang berkembang pada periode belakangan daripada sebagai catatan sejarah dalam pengertian

1 Mun'im Sirry, Kemunculan Islam Dalam Kesarjanan Revisionis (Yogyakarta: Suka Press, 2017), vii; Mun'im Sirry, Kontroversi Islam Awal: Antara Madhhab Tradisionalis dan Revisionis (Bandung: Mizan, 2015), 10. 
modern ${ }^{2}$. Sirry berkeyakinan bahwa Islam pada awalnya adalah ajaran ekumenis yang terbuka bagi berbagai agama monoteis ${ }^{3}$. Pemikirannya ini ia ringkas di bagian akhir dari bukunya dengan penekanan terhadap dipenuhinya buku-buku sejarah Islam yang sampai pada kita dewasa ini dengan tendensi pro-Abbasiyah sehingga mengabaikan kontribusi rezim Umayyah, dan dengan sendirinya menegasikan gagasan tentang sifat dasar agama Islam yang sebenarnya senantiasa berkembang dan berevolusi ${ }^{4}$.

Dari segi konten, sebagai "pembuka jalan” bagi diskusi Islam formatif, memang sudah semestinya Sirry memberikan porsi yang lebih besar dalam mendeskripsikan pemikiran-pemikiran kelompok revisionis sekaligus mengelaborasi bantahan dan kritik terhadap pemikiran-pemikiran tersebut. Kompleksitas argumentasi yang ingin disajikan menjadikan dua buku Sirry dipenuhi dengan analisa yang mendalam tentang pemetaan kesarjanaan revisionis. Dengan sifatnya yang demikian, menjadi tidak fair jika lantas buku itu dianggap merepresentasikan seutuhnya pemikiran Sirry sekaligus menjadikannya bagian dari kelompok revisionis radikal. Apalagi secara konkrit, Sirry memosisikan dirinya di tengah-tengah dengan menganjurkan umat Islam untuk membaca sumber-sumber tradisional Islam secara kritis: tidak menerima apa adanya sebagaimana kelompok tradisionalis pun tidak menolaknya secara membabi buta sebagaimana kelompok revisionis. ${ }^{5}$

Pada titik inilah artikel ini menemukan signifikansinya. Dengan memaparkan perdebatan mengenai salah satu buku revisionis, baik yang pro maupun yang kontra, gambaran tentang Islam revisionis tidak akan terlalu "mengerikan". Karya yang dimaksud adalah buku David Stevan Powers yang berjudul "Muhammad is Not the Father of Any of Your Men: The Making of The Last Prophet”. Judul buku

\footnotetext{
2 Sirry, Kontroversi Islam Awal: Antara Madhhab Tradisionalis dan Revisionis, 14.

3 Sirry, 15.

4 Sirry, 302-10.

5 Sirry, Kemunculan Islam Dalam Kesarjanan Revisionis, 316-17.
} 
Powers ini adalah terjemahan dari sebuah frasa dalam al-Ahzāb: 40 yang berbunyi: "mā kāna muḥammadun abā ạ̣adin min rijālikum". Secara umum, buku ini ingin menghadirkan teori tentang munculnya pemahaman mengenai posisi Muhammad sebagai Nabi terakhir, penutup para Nabi (Khätam al-Nabiyyīn) lewat kajian terhadap sosok Zaid Ibn Hāarithah, sang anak angkat.

Ada tiga alasan di balik pemilihan buku Powers ini sebagai obyek primer riset. Pertama, buku ini termasuk buku revisionis paling mutakhir, karena diterbitkan pada tahun 2009. Dibandingkan dengan buku-buku revisionis lain seperti John Wansbrough, ${ }^{6}$ ataupun duet Michael Cook dan Patricia Crone ${ }^{7}$, karya Powers ini lebih aktual untuk didiskusikan. Kedua, dari segi metodologi, karya Powers sangat kompleks. Dengan mengaplikasikan beberapa pendekatan sekaligus meliputi kajian literer terhadap sumber-sumber sejarah Islam tradisional, kajian intertekstualitas, dan kajian manuskrip alQur'an, Powers sampai pada kesimpulan yang bombastis. Kompleksitas metodologi yang digunakan Powers ini diapresiasi oleh beberapa peneliti sejarah Islam. G.R. Hawting dari SOAS menyanjung buku ini karena kekayaan hipotesis dan argumennya ${ }^{8}$, sementara Reuven Firestone, Professor kajian Yahudi dan Islam abad pertengahan mengumpamakan riset Powers ini sebagai petualangan akademik yang sulit dan berbahaya (it is not an expedition for the faint of heart) ${ }^{9}$. Ketiga, karya Powers yang mewakili kelompok revisionis radikal ini termasuk karya yang paling solid karena dikerjakan secara sungguh-

6 John Wansbrough, Qur'anic Studies: Sources and Methods of Scriptural Interpretation (Oxford: Oxford University Press, 1977); John Wansbrough, The Sectarian Milieu: Content and Composition of Islamic Salvation History (Oxford: Oxford University Press, 1978).

7 Patricia Crone and Michael Cook, Hagarism: The Making of Islamic World (Cambridge: Cambridge University Press, 1977).

8 G.R. Hawting, "Review on Muhammad Is Not the Father of Any of Your Men: The Making of The Last Prophet," Brill, Islamic Law and Society 18, no. 1 (2011): 116.

9 Reuven Firestone, "Review on Muhammad Is Not the Father of Any of Your Men," International Journal of Middle East Studies 44, no. 1 (2012): 179. 
sungguh oleh penulisnya. Tidak mengherankan jika Robinson menilai buku ini sebagai tour de force, ${ }^{10}$ sebuah perumpamaan untuk menyebut pencapaian istimewa seseorang yang sangat sulit bahkan mustahil dicapai oleh orang lain.

Buku setebal 356 halaman ini (termasuk indeks dan daftar pustaka), terbagi ke dalam 3 bagian. Bagian pertama memaparkan asumsi-asumsi Powers tentang hubungan antara Yahudi, Kristen dan Islam dan sejarah ringkas perilaku adopsi anak dalam budaya Near East hingga awal Islam. Bagian kedua dan ketiga yang merupakan bagian utama dalam buku ini, sebagaimana dirangkum oleh G.R. Hawting, mendiskusikan: (1) hubungan antara Nabi Muhammad dengan Zaid Ibn Hārithah sebagaimana digambarkan dalam sumber-sumber sejarah Muslim tradisional, yang menurut Powers adalah narasi buatan yang tidak bernilai historis; serta (2) kajian terhadap kata kalāah (keadaan seseorang yang tidak memiliki anak) pada manuskrip al-Qur'an yang menurut Powers sengaja disisipkan pada akhir abad pertama Hijriyah sebagai ganti dari kata yang sebenarnya (kallah yang berarti anak perempuan tiri $)^{11}$

Kedua Analisa ini dilakukan oleh Powers untuk membuktikan bahwa ada usaha sistematis dari umat Islam untuk menyegel pintu kenabian pasca Nabi Muhammad. Secara khusus, Powers meyakininya dilakukan di akhir abad pertama Hijriyah/ akhir abad ke-7 Masehi antara wafatnya Nabi pada $632 \mathrm{M}$ dan meninggalnya Khalifah 'Abd al-Mālik pada $705 \mathrm{M}^{12}$. Kesimpulan Powers ini mengamini apa yang terlebih dahulu diteorisasikan oleh Alphonse Mingana, Patricia

10 Chase F Robinson, "Review on Muhammad Is Not the Father of Any of Your Men: The Making of The Last Prophet: Divinations: Rereading Late Antiquity Religion by David Powers," Journal of the American Oriental Society 131, no. 1 (2011): 172.

11 Hawting, "Review on Muhammad Is Not the Father of Any of Your Men: The Making of The Last Prophet," 116.

12 David Stephan Powers, Muhammad Is Not the Father of Any of Your Men: The Making of the Last Prophet, Divinations (Philadelphia: University of Pennsylvania Press, 2009), 161. 
Crone dan Michael Cook. ${ }^{13}$ Agar lebih jelas, artikel ini akan memulai pembahasan dari grand design pemikiran Powers yang ingin ia sampaikan, baru kemudian menganalisa dua argumen utamanya. Review-review atas buku Powers juga akan diulas, selain tulisan-tulisan lain tentang Islam formatif.

\section{KHĀTAM AL-NABIYYIN DALAM BINGKAI “SALVATION HISTORY"}

Penelitian Powers bermula dari asumsinya bahwa dalam sejarah-sejarah agama semitik, hubungan kekeluargaan (ayah-anak) memainkan peran penting dalam status kenabian seseorang. Para Nabi seperti Ibrahim, Ishak, Yáqub, Musa, Dawud, Sulaiman dan Isa memiliki hubungan darah yang bahkan bersambung hingga Muhammad $^{14}$. Sebagaimana Isa, tegas Powers, Muhammad tidak memiliki anak laki-laki yang sempat sampai di usia matang. Berbeda dengan Isa yang tidak menikah, Muhammad memiliki belasan istri yang hanya dua di antara mereka (Khadijah dan Maria Qibțiyyah) yang sanggup memberinya anak. Dari semua anaknya, hanya Fatimah saja yang meninggal setelah Muhammad wafat. ${ }^{15}$

Sangat mengejutkan menurut Powers, bahwa konsep pewarisan kenabian ini tidak terdapat di dalam Islam yang justru menekankan bahwa pintu kenabian telah tertutup. Ini membuat Powers berhipotesa bahwa konsep tertutupnya pintu kenabian sebenarnya belum ada pada zaman Nabi. Lebih mengejutkan lagi bagi Powers, Zayd Ibn Ḥārithah (figur yang disebutkan dalam sumber tradisional sebagai anak angkat dari Muhammad) hampir tidak "dianggap" keberadaannya dalam sejarah Islam, sebuah perlakuan yang tidak wajar bagi satu-satunya

13 Mohammad Ali Amir-Moezzi et al., The Silent Quran \& the Speaking Quran: Scriptural Sources of Islam between History and Fervor (New York: Columbia University Press, 2016), 48.

14 Powers, Muhammad Is Not the Father of Any of Your Men, 8.

15 Powers, 9. 
orang selain Muhammad sendiri yang namanya disebut di dalam alQur'an (Q. 33: 37). ${ }^{16}$ Basis keragu-raguan Powers ini menunjukkan bagaimana ia meyakini adanya pattern khas yang mengikat semua agama samawi.

Dalam sejarah Islam tradisional, Muhammad diceritakan memiliki dua orang putra yang potensial menjadi penerus status kenabian jika keduanya masih hidup setelah Rasul wafat. Sayangnya, keduanya meninggal sebelum itu terjadi. Putra biologis Muhammad, 'Abdullah meninggal ketika masih balita, sedangkan Zayd Ibn $\mathrm{H}$ \}a $>$ rithah, seorang budak yang diadopsi oleh Muhammad mati syahid di perang Mu'tah.

Tak banyak yang mengetahui, kalau Zayd Ibn Ḥārithah adalah seorang pemuda yang mendapat perlakuan khusus dari Nabi. Ketika diadopsi oleh Muhammad, usia Zaid sepuluh tahun lebih muda dari sang Nabi. Seketika itu, Zayd dijuluki Zayd al-Hibb (Zayd yang dicintai) atau Hibb Rasūlillāh (Kekasih Rasulullah). Ia juga adalah pemuda pertama yang memeluk Islam. Pasca diadopsi, Zayd menjadi bagian dari Ahl al-Bayt. Zayd adalah seorang petarung serta pemanah yang unggul sehingga Nabi mengangkatnya menjadi komandan perang dalam sembilan ekspedisi militer. Potensialitas Zayd menjadi penerus kenabian bahkan terilustrasikan dalam sebuah perkataan dari 'Aishah, yang ia ucapkan tatkala mendengar Zayd meninggal dalam perang Mu'tah. 'Aisyah berkata: 'Rasul tidak pernah mengutus Zayd dalam sebuah ekspedisi militer kecuali menunjuknya sebagai komandan. Andaikan Zayd masih hidup sepeninggal Rasulullah, pastilah ia akan dijadikan penerusnya'. Narasi di atas didapatkan Powers dari kolaborasi antara tradisi-tradisi yang berkembang di kalangan umat Islam sendiri serta penelitian-penelitian para orientalis. Di antara rujukan yang ia gunakan adalah Kitāb al-Ṭabaqāt al-Kabīr dan al-Ṭabaqāt al-Kubrā karya Ibn Sa'd, Tärīkh Madinah Dimashq karya Ibn 'Asākir, al-Ansāb

16 Firestone, "Review on Muhammad Is Not The Father of Any of Your Men," 180. 
karya al-Balāụuri, Tärikh al-Tabarīi, serta beberapa tulisan orientalis seperti CF. Kister, Madelung dan M. Watt. ${ }^{17}$

Jika Zayd istimewa, begitu pula dengan anaknya, Usa $>$ mah Ibn Zayd. Cinta Rasul terhadap Usāmah dikabarkan sama dengan cintanya terhadap dua cucu biologisnya: al-Ḥasan dan al-Ḥusayn. Usāmah dijuluki Hibb Ibn Hibb Rasūlillāh (anak kesayangan dari kesayangan Rasulullah). Sebagai seorang pejuang handal, di usianya yang ke20, Usāmah telah dipercaya oleh Muhammad untuk memimpin sebuah ekspedisi militer ke Yordania Selatan. Pada ekspedisi itulah, ia mendapat kabar bahwa Rasul meninggal dunia. Usāmah lantas kembali ke Medinah dan ikut memandikan jasad sang Nabi serta menurunkannya ke liang lahat bersama dengan lima orang keluarga Nabi yang lain.

Para sahabatpun memberi perlakukan khusus terhadap Usāmah . Pasca kepulangannya dari ekspedisi militer, 'Umar Ibn al-Khaț̣āb memberinya empat ribu dirham, jauh lebih banyak daripada anak 'Umar sendiri, 'Abdullāh. ketika diprotes, 'Umar menjawab bahwa Rasul sendiri lebih menyayangi Zayd daripada 'Umar, dan karenanya Rasul pasti lebih menyayangi pula Usāmah Ibn Zayd daripada 'Adullāh Ibn 'Umar' ${ }^{18}$. Melihat keistimewaan di atas, sungguh sangat disayangkan jika Zayd meninggal sebelum wafatnya Nabi sehingga status kenabian-pun menjadi tertutup karena Muhammad tidak meninggalkan seorang anak laki-laki yang matang usianya ketika ia meninggal. Begitulah kira-kira jalan pikiran Powers.

Sebelum mengulas temuan-temuannya, kita perlu mengetahui terlebih dahulu, mengapa isu tentang "Muhammad sebagai Nabi terakhir" ini dianggap penting oleh Powers. Dalam kesimpulan bukunya, Powers mengatakan: ${ }^{19}$

17 Powers, Muhammad Is Not the Father of Any of Your Men, 25-28.

18 Powers, 27.

19 Powers, 225. 
"The office of prophecy is the exclusive possession of a single family, the descendants of Abraham. Key figures mentioned in the Hebrew Bible and New Testament, including Moses, David, and Jesus, were all true prophets who received divine revelations. Over time, however, the revelation delivered to those prophets underwent tahrifor scriptural distortion. Mistakes crept into the Torah and the New Testament, and these texts ceased to be reliable sources of divine will. This is why God sent Muhammad to the Arabs. As a lineal descendant of Ishmael, Muhammad was a member of the family to which the office of prophecy had been entrusted. The Purpose of his mission was to restore the original, uncorrupted version of the earlier revelations. Only the faithful and accurate preservation of the revelations received by Muhammad makes it possible for the Muslim community to assert with confidence that he was the Last Prophet and that the office of prophecy terminated upon his death".

"Status kenabian adalah milik khusus dari sebuah keluarga, yaitu keturunan Ibrahim. Tokoh-tokoh penting yang disebutkan dalam Perjanjian Lama dan Perjanjian Baru, termasuk Musa, Dawud, Isa, semuanya adalah nabi-nabi yang menerima wahyu ilahi. Seiring berjalannya waktu, wahyu-wahyu yang sampai kepada nabi-nabi tersebut mengalami tahriffatau distorsi skriptural. Kesalahan-kesalahan disisipkan ke dalam Taurat dan Injil, kemudian teks-teks (tambahan) ini dianggap sebagai sumber ajaran ilahi yang bisa dipegangi. Inilah mengapa Tuhan mengutus Muhammad kepada bangsa Arab. Sebagai keturunan langsung dari Ishmael, Muhammad adalah anggota keluarga yang mendapatkan kepercayaan untuk mengemban status kenabian. Tujuan utama misinya adalah untuk memulihkan versi kitab-kitab terdahulu yang asli dan tidak terkorupsi. Hanya dengan menjaga secara penuh wahyu yang diterima oleh Muhammad, umat Islam bisa meyakini dengan pasti bahwa Muhammad adalah sang Nabi Terakhir dan bahwa pintu kenabian telah tertutup pasca wafatnya”.

Kita sepatutnya memberikan perhatian kepada bagian akhir dari kesimpulan Powers tersebut. Dengan memberikan penekanan pada posisi wahyu yang diterima oleh Muhammad di antara wahyu-wahyu yang 
turun pada nabi-nabi sebelumnya, Powers hendak mengatakan bahwa doktrin 'Muhammad sebagai penutup para Nabi' sengaja dimunculkan untuk mengukuhkan superioritas Islam sebagai agama semitik terakhir yang final, paling sempurna dan mengoreksi agama-agama terdahulu yang telah diselewengkan. Tak hanya membuat Islam superior atas agama lain, doktrin ini juga mampu mengantisipasi munculnya agama baru di kemudian hari yang mungkin akan memperlakukan Islam sama dengan perlakuannya terhadap Yahudi dan Nasrani. ${ }^{20}$

Ide Powers ini merepresentasikan posisinya sebagai seorang revisionis yang menganggap sejarah Islam yang tergambar dalam sumber-sumber tradisional sebagai salvation history (sejarah penyelamatan), ${ }^{21}$ yaitu sejarah mengenai bagaimana Tuhan melindungi Nabi dan bangsa Arab yang sebaiknya terjadi, bukan yang sebenarnya terjadi. ${ }^{22}$ Dengan demikian menurut Powers, konsep tertutupnya kenabian juga turut di-install dalam narasi sejarah penyelematan ini lewat penokohan seorang Zayd. Tokohnya mungkin tidak signifikan jika dilihat dari lensa sejarah Islam secara umum, tapi dari kaca mata sejarah penyelamatan, Zayd memainkan peran vital karena kisahnyalah yang membuat Muhammad bisa menjadi "Nabi Terakhir". 23

Sebelum mengelaborasi bagaimana Powers membuktikan klaimnya, terlebih dahulu akan dilihat respon para pakar sejarah Islam lain tentang dua asumsi utama Powers (genealogi kenabian dan doktrin tertutupnya pintu kenabian dalam Islam) untuk mengilustrasikan bahwa bahkan dalam asumsi paling dasarnya sekalipun, cara berpikir kelompok revisionis sudah cukup kontroversial. Menyambut baik ide Powers tentang genealogi kenabian, Firestone mempertanyakan posibilitas kenabian dari keturunan Ibrahim yang lain secara umum, atau klan Hāshim secara khusus sebagai keturunan Ishmael jika

20 Firestone, "Review on Muhammad Is Not the Father of Any of Your Men," 181.

21 Wansbrough, The Sectarian Milieu: Content and Composition of Islamic Salvation History.

22 Sirry, Kontroversi Islam Awal: Antara Madhhab Tradisionalis dan Revisionis, 51.

23 Powers, Muhammad Is Not the Father of Any of Your Men, 227. 
Muhammad dianggap tidak memiliki penerus. Secara retorik, Firestone menanyakan "Could there not be a hidden prophetic spark in any of these waiting to emerge when the time is right?" (apakah tidak mungkin terdapat jalur kenabian yang tersembunyi dan sedang menunggu untuk muncul ketika waktunya tepat?). ${ }^{24}$

Madelung memberikan gambaran yang lebih konkrit tentang tawaran Powers terhadap revisi sejarah Islam yang selama ini dipahami, khususnya yang berkaitan dengan sosok penerus kenabian Muhammad. Selama ini, kesarjanaan Barat menerima begitu saja ketiadaan penerus kenabian dalam Islam yang mengkristal dalam perpecahan antara kelompok Sunni dan Shiah. Menurut Madelung, Powers jelas terpengaruh ide Shi'ah bahwa Muhammad telah menyiapkan penggantinya jika ia wafat. Hanya saja, dalam konspirasi versi Powers ini, korbannya bukan 'Ali Ibn Ab̄i Ṭālib, melainkan Zayd dan Usāmah.

Pada titik ini, banyak yang mungkin menanyakan, jika benar Zayd adalah penerus kenabian, mengapa para pendukung Zayd tidak tercatat pernah melakukan gerakan protes atau semacamnya. Point yang terakhir ini belum dan memang tidak menjadi fokus Analisa Powers yang lebih tertarik dengan kajian komparasi antara sejarah Islam dan narasi-narasi biblikal ${ }^{25}$. Tentu, alibi Powers ini masih menyisakan masalah yang serius mengingat gejolak pengikut Zayd, jika memang ada, tidak pernah terekam dalam sejarah Islam atau paling tidak belum berhasil dibuktikan.

Kelemahan asumsi utama Powers juga ditangkap oleh G.R. Hawting yang masih meragukan apakah memang di abad pertama Hijriyah dunia Islam menganggap status kenabian adalah "warisan" dari ayah

24 Firestone, "Review on Muhammad Is Not The Father of Any of Your Men," 181.

25 Wilfred Madelung, "Review on Muhammad Is Not the Father of Any of Your Men: The Making of The Last Prophet (Divinations: Rereading Late Ancient Religion)," The University of Chicao Press on Behalf of The Medieval Academy of America 85, no. 3 (2010): 728. 
ke anak. Hawting tidak menafikan genealogi kenabian ini ada pada budaya Near-Eastern dan Mediterranian, tetapi ia mengingatkan bahwa dalam keimanan kaum monoteis, status kenabian diberikan oleh Tuhan secara preogratif dan tak seorangpun benar-benar tahu rahasia di balik pemilihan tersebut. Dalam al-Qur'an, lanjut Hawting, meskipun disebutkan figur-figur seperti Ibrahim, Sulaiman dan Dawud, terlalu berlebihan jika disebut mereka semua menjadi Nabi karena status warisan (there is little sense that that is the result of inheritance) ${ }^{26}$. Hal yang sama juga disampaikan oleh Walid Saleh. Menurutnya, Islam adalah Islam, bukan Yahudi atau Nasrani. Dalam Islam, tegas Saleh, hubungan ayah-anak bukanlah motif utama dalam al-Qur'an. ${ }^{27}$

Asumsi kedua Powers mengenai proses kristalisasi dogma tertutupnya kenabian di dunia Islam pada akhir abad pertama Hijriyah juga dipertanyakan. Robinson menganggap penjelasan Powers untuk klaim di atas tidak memadai. Secara khusus, Robinson mengutip artikel Evstatiev yang menyatakan bahwa pada abad kedua Hijriyah pun, isu tentang tertutupnya pintu kenabian masih menjadi polemik ${ }^{28}$. Evstatiev menampilkan sebuah dokumen resmi khalifah al-Wali>d II Ibn Yazi $>d$ (125/743) yang memakai kata kha>tam al-Nabiyyi $>n$ tidak untuk menunjukkan "finalitas pewahyuan", melainkan lebih kepada konfirmasi atas rantai kenabian yang diteruskan Muhammad dari Nabi-nabi terdahulu. ${ }^{29}$

26 Hawting, "Review on Muhammad Is Not The Father of Any of Your Men: The Making of The Last Prophet," 117.

27 Walid A. Saleh, "Review Article: Muhammad Is Not the Father of Any of Your Men: The Making of the Last Prophet, by David S. Powers. University of Pennsylvania Press, 2009. 376 Pp., 7 Illus. Hb \$55.00/£36.00. ISBN-13: 9780812241785.", Comparative Islamic Studies 6, no. 6.1-6.2 (December 29, 2011): 264, https://doi.org/10.1558/cis.v6i1-2.251.

28 Robinson, "Review on Muhammad Is Not The Father of Any of Your Men: The Making of The Last Prophet: Divinations: Rereading Late Antiquity Religion by David Powers," 173.

29 Simeon Evstatiev, "On The Perception of the Khătam Al-Nabiyyin, Doctrine in Arabic Historical Thought: Confirmation or Finality," in Studies in Arabic and Islam (Proceedings of the 19th Congress, Union Europeenne Des Arabisants et Islamisants, Halle, 1998) (Leuven: UITGEVERIJ PEETERS, 2002), 457-58. 
Kritik lebih tajam juga diberikan oleh Walid Saleh yang menganalogikan Powers seperti orang yang membuat kue lalu memakannya sendiri (has a cake and eats it too).$^{30}$ Ketidakpercayaan Powers terhadap reliabilitas sumber-sumber Islam tradisional membuatnya secara membabi buta menganggap semua informasinya sebagai fiksi dan fabula. Saleh menuduh Powers telah menganggap bohong tidak hanya narasi-narasi tradisional tentang sosok Zayd, tetapi juga seluruh narasi tentang Islam formatif dalam sumber tradisional. Menurut Saleh, ketergesa-gesaan Powers menyimpulkan finalisasi doktrin Muhammad sebagai Nabi terakhir dapat diruntuhkan dengan membaca narasi Islam tentang sudah munculnya wacana doktrin tersebut sejak wafatnya Muhammad. Munculnya nabi-nabi palsu serta perang terhadap orang-orang murtad menunjukkan hal tersebut. Mengenai hal ini, Saleh menuduh Powers tidak bersikap adil dalam melakukan Analisa karena perang riddah hanya sekilas saja disebutkan dalam halaman 80 tanpa dielaborasi lebih lanjut. Pilihan metodologi Powers yang justru asyik membandingkan sejarah Islam dengan tradisi Midras Yahudi membuatnya men-dehistorisasi Islam itu sendiri. ${ }^{31}$

Sebagai penutup, di satu sisi, Saleh benar bahwa pendekatan intertekstualitas revisionis radikal seperti yang diperagakan oleh Powers telah mengaburkan sejarah Islam alih-alih membuatnya terang-benderang. Tetapi di sisi lain, kritik Saleh tidak cukup kuat untuk meruntuhkan basis argumentasi Powers. Pertama, kapan isu tentang "Muhammad sebagai Nabi terakhir" berakhir tidak begitu penting bagi Powers, selagi ia bisa membuktikan ada kesamaan yang signifikan antara tradisi Islam dengan tradisi Yahudi dan Nasrani. Kedua, di halaman 53 dan 54 bukunya, Powers telah menyinggung pendapat Friedmann tentang pergeseran makna khätam al-Nabiyyīn dari "Seal of Prophets" ke "Last Prophet" yang barangkali sudah ada

30 Saleh, "Review Article," 262.

31 Saleh, 262. 
sejak Nabi masih hidup ${ }^{32}$. Hanya saja, Powers bersikukuh bahwa pada akhir abad pertama Hijriyah-lah anggapan mengenai Muhammad sebagai nabi terakhir muncul bersamaan dengan anggapan bahwa dia menyempurnakan ajaran-ajaran terdahulu ${ }^{33}$. Bisa jadi Powers melakukan simplifikasi permasalahan, yang meskipun tidak fatal menurutnya, tapi cukup mengganggu perhatian para pemerhati sejarah Islam.

\section{KISAH ZAYD DALAM Q. 33: 36-40, 4-6; LEGENDA ATAU SEJARAH?}

Untuk membuktikan klaimnya bahwa dogma teologis tentang tertutupnya kenabian sengaja dibuat oleh umat Islam, Powers meyakini dua hal: (1) bahwa sedikit revisi telah ditambahkan pada teks alQur'an, dan (2) bahwa sosok Zayd dengan segala dramanya sengaja diciptakan. Point kedua akan dielaborasi terlebih dahulu, dan untuk itu kita perlu melihat lebih dekat al-Aḥzāb: 4-6 dan 36-40, sebagaimana yang dilakukan Powers. Bukan tanpa alasan, Powers mengusulkan untuk membaca dua gugusan ayat ini dari ayat ke-36, alih-alih ayat ke-4. Powers berkeyakinan, model pembacaan ini lebih kronologis dan menggambarkan sebuah alur cerita yang runtut. ${ }^{34}$ Ayat-ayat tersebut adalah sebagai berikut:

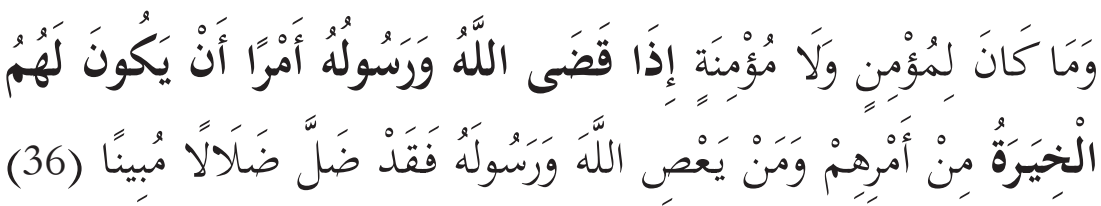

32 Yohanan Friedmann, "Finality of Prophethood in Sunni Islam," Jerusalem Studies in Arabic and Islam 7 (1986): 177-215; Di tulisannya yang lain, Friedmann menyebut beberapa nabi palsu dari berbagai masa seperti al-Aswad, Musaylamah, al-Mukhta $>\mathrm{r}$ (w. 67/ 687), al-H\}a >rith Ibn Sa'i >d (w. 79/699) serta Abu> 'Isa> al-Isfaha>ni>. Yohanan Friedmann, Prophecy Continues: Aspects of Ahmadi Religions Thought and Its Medieval Background (Berkeley: University of California Press, 1989).

33 Powers, Muhammad Is Not the Father of Any of Your Men, 53-54.

34 Powers, 39-40. 


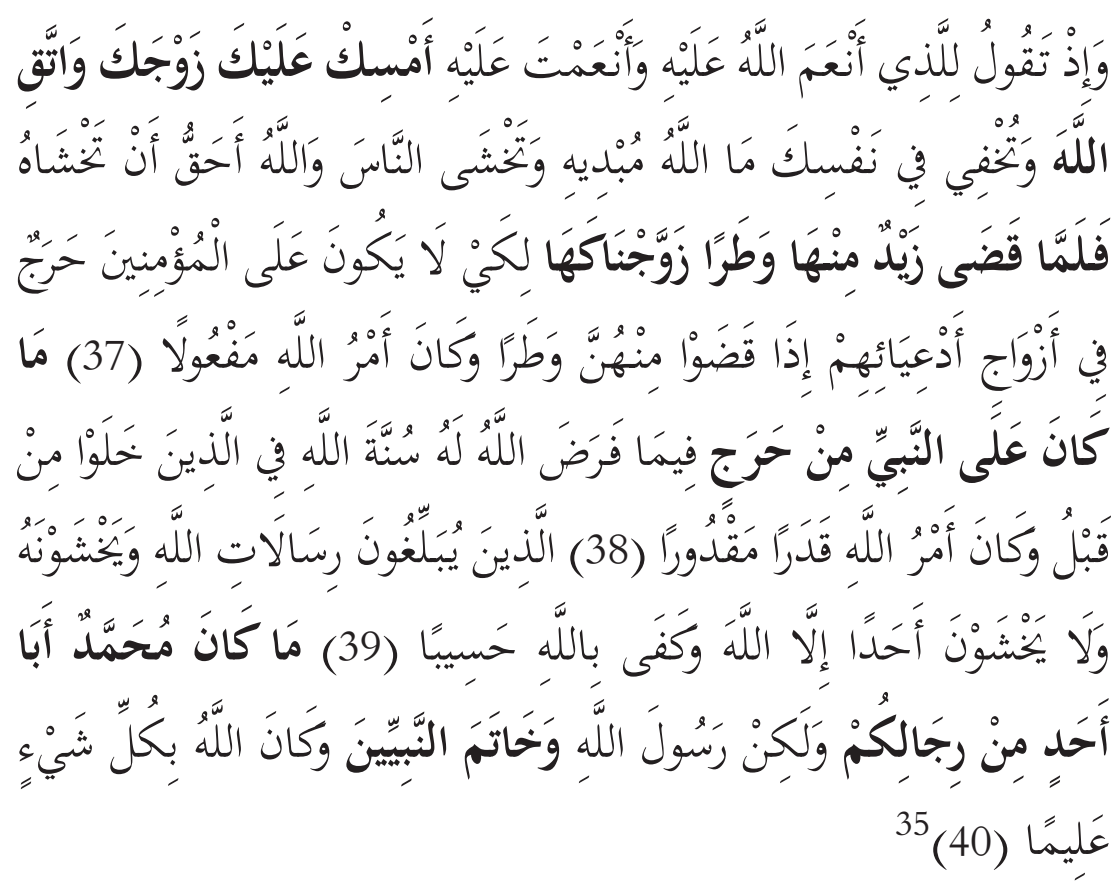

35 Dan tidaklah patut bagi laki-laki yang mukmin dan tidak (pula) bagi perempuan yang mukmin, apabila Allah dan Rasul-Nya telah menetapkan suatu ketetapan, akan ada bagi mereka pilihan (yang lain) tentang urusan mereka. Dan barangsiapa mendurhakai Allah dan Rasul-Nya maka sungguhlah dia telah sesat, sesat yang nyata (36). Dan (ingatlah), ketika kamu berkata kepada orang yang Allah telah melimpahkan nikmat kepadanya dan kamu (juga) telah memberi nikmat kepadanya: "Tahanlah terus isterimu dan bertakwalah kepada Allah", sedang kamu menyembunyikan di dalam hatimu apa yang Allah akan menyatakannya, dan kamu takut kepada manusia, sedang Allah-lah yang lebih berhak untuk kamu takuti. Maka tatkala Zaid telah mengakhiri keperluan terhadap istrinya (menceraikannya), Kami kawinkan kamu dengan dia supaya tidak ada keberatan bagi orang mukmin untuk (mengawini) isteri-isteri anak-anak angkat mereka, apabila anak-anak angkat itu telah menyelesaikan keperluannya daripada isterinya. Dan adalah ketetapan Allah itu pasti terjadi (37). Tidak ada suatu keberatanpun atas Nabi tentang apa yang telah ditetapkan Allah baginya. (Allah telah menetapkan yang demikian) sebagai sunnah-Nya pada nabi-nabi yang telah berlalu dahulu. Dan adalah ketetapan Allah itu suatu ketetapan yang pasti berlaku (38). (yaitu) orang-orang yang menyapaikan risalah-risalah Allah, mereka takut kepada-Nya dan mereka tiada merasa takut kepada seorang(pun) selain kepada Allah. Dan cukuplah Allah sebagai Pembuat Perhitungan (39). Muhammad itu sekali-kali bukanlah bapak dari seorang laki-laki di antara kamu, tetapi dia adalah Rasulullah dan penutup nabi-nabi. Dan adalah Allah Maha Mengetahui segala sesuatu (40). 


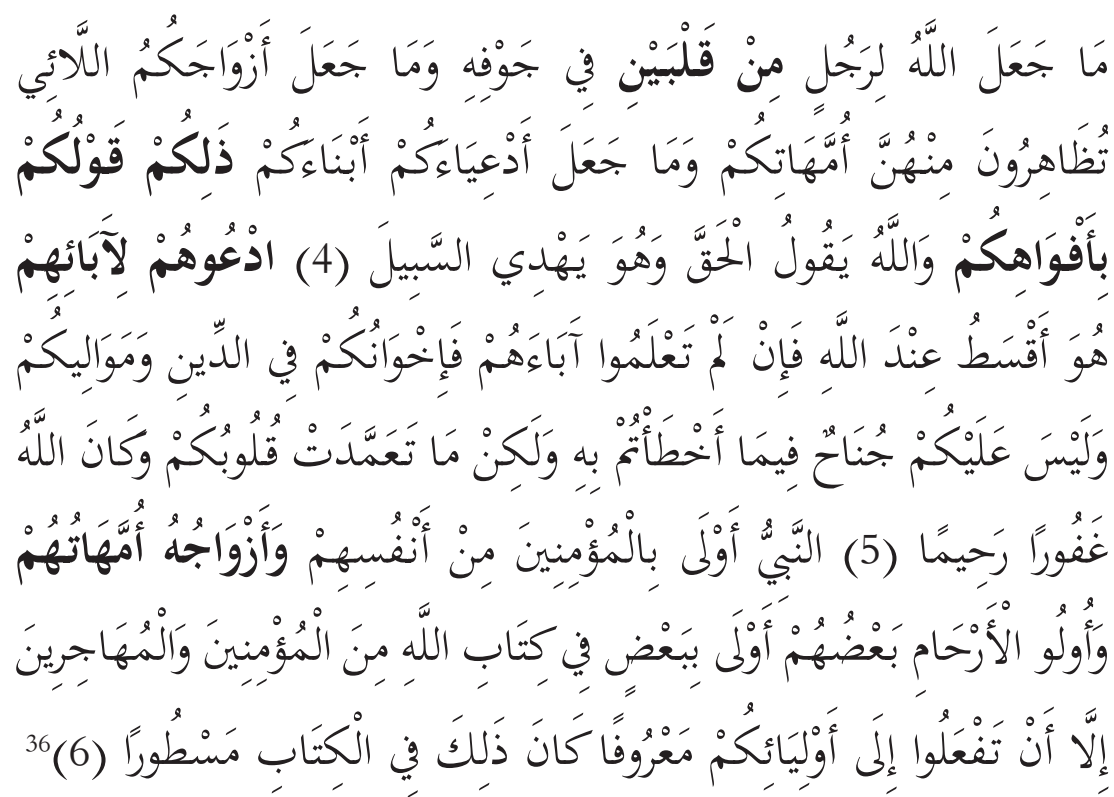

Strategi berikutnya adalah membaca ayat-ayat tersebut lewat tafsir Muqātil Ibn Sulaymān (w. 150/ 767), kitab tafsir generasi awal yang secara khusus mengaitkan-utamanya ayat ke-37-dengan Zaynab Bint Jah\}sh, istri Zayd Ibn Hāarithah serta berbicara panjang lebar tentang kisah trilogi Muhammad-Zaynab-Zayd. Dengan membaca kitab Muqātil berdasarkan urutan yang Powers telah tentukan, Powers

36 Allah sekali-kali tidak menjadikan bagi seseorang dua buah hati dalam rongganya; dan Dia tidak menjadikan istri-istrimu yang kamu zhihar itu sebagai ibumu, dan Dia tidak menjadikan anak-anak angkatmu sebagai anak kandungmu (sendiri). Yang demikian itu hanyalah perkataanmu dimulutmu saja. Dan Allah mengatakan yang sebenarnya dan Dia menunjukkan jalan (yang benar) (4). Panggilah mereka (anak-anak angkat itu) dengan (memakai) nama bapak-bapak mereka; itulah yang lebih adil pada sisi Allah, dan jika kamu tidak mengetahui bapak-bapak mereka, maka (panggilah mereka sebagai) saudarasaudaramu seagama dan maula-maulamu. Dan tidak ada dosa atasmu terhadap apa yang kamu khilaf padanya, tetapi (yang ada dosanya) apa yang disengaja oleh hatimu. Dan adalah Allah Maha Pengampun lagi Maha Penyayang (5). Nabi itu (hendaknya) lebih utama bagi orang-orang mukmin dari diri mereka sendiri dan isteri-isterinya adalah ibuibu mereka. Dan orang-orang yang mempunyai hubungan darah satu sama lain lebih berhak (waris-mewarisi) di dalam Kitab Allah daripada orang-orang mukmim dan orangorang Muhajirin, kecuali kalau kamu berbuat baik kepada saudara-saudaramu (seagama). Adalah yang demikian itu telah tertulis di dalam Kitab (Allah) (6). 
lantas mem-break down fase-fase kisah Zayd ini ke dalam beberapa fragmen berikut ini: ${ }^{37}$

Tabel 1.

Fragmen Kisah Muhammad-Zayd-Zaynab versi Powers

\begin{tabular}{|c|c|c|}
\hline Tema Besar & Detil & Ayat \\
\hline \multirow{3}{*}{$\begin{array}{l}\text { Kesayangan } \\
\text { Rasulullah }\end{array}$} & $\begin{array}{l}\text { a. Penangkapan Zayd dan } \\
\text { Akuisisinya oleh Khadijah }\end{array}$ & \multirow{3}{*}{ (Q. 33: 36-38) } \\
\hline & $\begin{array}{l}\text { b. Zayd diadopsi oleh } \\
\text { Muhammad }\end{array}$ & \\
\hline & $\begin{array}{l}\text { c. Zayd menikah dengan } \\
\text { Zaynab }\end{array}$ & \\
\hline \multirow{3}{*}{$\begin{array}{l}\text { Pernikahan di } \\
\text { dalam surga }\end{array}$} & $\begin{array}{l}\text { a. Ketertarikan seksual antara } \\
\text { Muhammad dan Zaynab }\end{array}$ & \multirow{3}{*}{$\begin{array}{l}\text { (Q. 33: 36-38 } \\
\text { Cont.) }\end{array}$} \\
\hline & $\begin{array}{l}\text { b. Membuat Zayd } \\
\text { menceraikan Zaynab }\end{array}$ & \\
\hline & $\begin{array}{l}\text { C. Zaynab dinikahi } \\
\text { Muhammad }\end{array}$ & \\
\hline \multirow{2}{*}{$\begin{array}{l}\text { 3. Reaksi publik } \\
\text { terhadap } \\
\text { pernikahan } \\
\text { Muhammad } \\
\text { dan Zaynab }\end{array}$} & $\begin{array}{l}\text { a. Apakah pernikahan tersebut } \\
\text { termasuk perzinahan } \\
\text { (incest) }\end{array}$ & $\begin{array}{l}\text { (Q. 33: } 37 \\
\text { Cont.) }\end{array}$ \\
\hline & $\begin{array}{l}\text { b. Ketentuan Allah } \\
\text { (Sunnatullāh) }\end{array}$ & (Q. 33: 38) \\
\hline \multicolumn{2}{|c|}{ 4. Muhammad sebagai penutup para Nabi } & (Q. 33: 40) \\
\hline
\end{tabular}

37 Powers, Muhammad Is Not the Father of Any of Your Men, 40-63. 


\begin{tabular}{|c|c|c|}
\hline \multirow{3}{*}{$\begin{array}{l}\text { 5. Konskuensi } \\
\text { Hukum }\end{array}$} & $\begin{array}{l}\text { a. Penyangkalan Muhammad } \\
\text { atas Zayd }\end{array}$ & (Q. 33: 4-5) \\
\hline & $\begin{array}{l}\text { b. Pencabutan adopsi, diikuti } \\
\text { dengan }\end{array}$ & $\begin{array}{l}\text { (Q. 33: 4-5 } \\
\text { Cont.) }\end{array}$ \\
\hline & $\begin{array}{l}\text { c. Pelarangan menikah dengan } \\
\text { janda-janda Nabi. }\end{array}$ & (Q. 33: 6). \\
\hline
\end{tabular}

Sekilas, fragmen cerita yang disusun oleh Powers ini terlihat provokatif. Misalnya Aksi 2.a tentang ketertarikan Nabi secara fisik kepada Zaynab. Namun, terlepas dari kontroversi seputar tafsir Muqātil, memang begitulah Muqa>til menafsirkan kisah Zayd. Menurut Muqātil, Muhammad memiliki hasrat kepada Zaynab (hawiyahā) dan terpukau dengan kecantikan dan kemolekan tubuhnya (a'jabahū ḥusnuhā wa jamāluhā wa ḍarfuhā).$^{38}$ Setiap fragmen dalam cerita di atas didukung oleh informasi-informasi yang dinukil Powers dari kitab-kitab sejarah seperti Tārỉkh al-Tabarī, Majma' al-Bayān karya al-Tabarsī, Tārikh Madinat Dimashq karya Ibn 'Asākir serta yang paling dominan tentu dari Tafsir Muqātil sendiri. Dalam artikel ini, hanya beberapa isu penting saja yang akan dielaborasi.

Salah satunya adalah analisa Powers tentang kata sunnatullāh dalam al-Ạ̣zāb: 38. Powers menyimpulkan adanya keserupaan antara kisah Muhammad-Zayd-Zaynab dengan Dawud-Uriah-Bathsheba. ${ }^{39}$ Dalam narasi Biblikal, disebutkan bahwa Dawud yang sudah memiliki 99 istri masih berhasrat kepada seorang wanita bernama Bathsheba yang merupakan istri dari Uriah. Dawud lantas melakukan intrik dengan mengirimkan Uriah berperang di mana Uriah meninggal dalam perang itu dan Dawud akhirnya bisa menikahi Bathsheba. Penyamaan (juxtaposition)

38 Muqātil Ibn Sulaimān, Tafsīir Muqātil Ibn Sulaimān, ed. 'Abdullāh Maḥmūd Shaḥh àtah, vol. 3 (al-Hay'ah al-Mis\}riyyah al-'A >mmah, 1979), 492-93.

39 Powers, Muhammad Is Not the Father of Any of Your Men, 49. 
antara kisah Dawud-Bathsheba dengan Muhammad-Zaynab, menurut Powers, sangat penting bagi komunitas Muslim awal untuk menekankan bahwa sejarah umat manusia berjalan seiring dengan sunnatullăh. ${ }^{40}$

Kita bisa melihat bahwa pilihan Powers untuk membaca dua gugusan ayat dalam surah al-Ahyāab dari belakang (ayat ke 36-40) memainkan peran besar dalam kisah yang ditawarkannya. Metodologi Powers ini jelas mempertimbangkan aspek-aspek kronologis dalam surah al-Aḥzāb. Berdasarkan sumber-sumber tradisional, Noldeke menunjukkan bahwa di dalam surah al-Aḥāōb, terdapat beberapa gugusan ayat yang bisa diperkirakan waktu turunnya. Ayat ke-9-27 misalnya disinyalir terjadi pada akhir tahun $5 \mathrm{H} / 626 \mathrm{M}$ pasca perginya pasukan aliansi suku Quraish, Ghațafān dan Qurayḍa dari Madinah dalam perang parit. Di tahun yang sama, terjadilah pernikahan antara Muhammad dan Zaynab sebagaimana ditunjukkan oleh ayat ke-36-40. Sementara untuk ayat-ayat pertama dalam surah al-Ahzāo, Noldeke tidak memiliki data untuk menentukan penanggalan terhadapnya, meskipun ia mengakui adanya keterkaitan konsep antara ayat-ayat pertama tersebut dengan ayat-ayat tentang pernikahan Muhammad dan Zaynab ${ }^{41}$. Sedikit berbeda dengan Noldeke, meskipun al-Jābirì menanggali perang parit pada $4 \mathrm{H}$, ia juga mengaitkan ayat ke-4-6 dengan kasus Zayd pada ayat ke-36-40. ${ }^{42}$

Tetapi, Powers memiliki alasan tertentu mengapa ia harus membaca kisah Zayd dari belakang. Menurutnya, siapapun yang menyusun al-Qur'an ${ }^{43}$ telah dengan sengaja memisah dua gugusan ayat tersebut dan meletakkan bagian yang seharusnya di akhir menjadi di depan. Dengan cara ini, hubungan kasualitas hukum (fragmen nomor 5 dalam alur Powers) menjadi kabur. Alasan lainnya adalah,

\footnotetext{
40 Powers, 50.

41 Theodor Noldeke et al., The History of The Qur'an, trans. Wolfgang Behn (Leiden, 2013), $167-68$.

42 Muhammad 'Ābid al-Jābirī, Fahm al-Qur'ān al-hakīm:: at-tafsīr al-wādih hasab tartīb annuzūl. Qism 3: [...], Țab`a 1 (Bairūt: Markaz Dirāsāt al-Waḥda al-'Arabīya, 2009), 183-87. 43 Powers termasuk orientalis radikal yang meragukan orisinalitas al-Qur’an.
} 
dengan meletakkan bagian cerita di awal, pembaca telah bisa menerka bahwa kisahnya akan berakhir dengan penganuliran status anak Zayd oleh Muhammad ${ }^{44}$. Pada intinya, Powers menuduh umat Islam telah melakukan konspirasi dalam mengkonstruksi kisah Zayd. Sedari awal, keberadaan seorang Zayd Ibn Muhammad ${ }^{45}$ dianggap mengancam doktrin tertutupnya pintu kenabian yang ingin dibakukan oleh umat Islam, apalagi Zayd sempat menjadi lelaki yang berusia matang sebelum tewas di Mut'ah dan darinya lahir Usāmah. Karena alasan tertentu, umat Islam harus melakukan sesuatu untuk memutus mata rantai ini, dengan memakai satu dari dua cara: memutus hubungan antara Zayd dengan Usāmah atau antara Muhammad dengan Zayd. Pada akhirnya menurut Powers, opsi kedua dianggap lebih masuk akal sehingga narasi tentang dianulirnya status anak Zayd oleh Muhammad perlu disisipkan ${ }^{46}$. Hasil penelusuran Powers tentang figur Zayd dalam sumber-sumber tradisional mengantarkan dia pada kesimpulan yang kontroversial, sebagai berikut: ${ }^{47}$

"Muhammad may have had an adopted son named Zayd and a natural son named Ibrahim, but the statements made about these two sons in the narratives examined in this chapter are best seen as salvation history. The fact that these two individuals are represented as historical figures should not mislead us into thinking that the content of these forms corresponds to any historical reality... The original function of the narratives about these two individuals was to confirm the truth of the theological doctrine that Muhammad is the last Prophet. To this end, the early Muslim community formulated a sacred legend,.."

"Muhammad mungkin saja memiliki anak adopsi bernama Zayd serta anak biologis bernama Ibrahim, tetapi pernyataan-pernyataan tentang

44 Powers, Muhammad Is Not the Father of Any of Your Men, 58.

45 Pada awalnya, sebelum hukum tentang adopsi dianulir, nama seseoang akan dinisbahkan kepada ayah angkatnya.

46 Powers, Muhammad Is Not the Father of Any of Your Men, 57-66.

47 Powers, 68-69. 
kedua anak dalam kisah-kisah yang dikaji di bab ini seyogyanya dilihat sebagai (bagian dari) sejarah penyelamatan. Fakta bahwa dua individu ini digambarkan sebagai figur-figur historis seharusnya tidak membuat kita serta-merta berpikir bahwa konten ceritanya memang beradasarkan pada realitas historis... fungsi asli dari kisah-kisah tentang dua individu ini adalah untuk mengkonfirmasi kebenaran doktrin teologis bahwa Muhammad adalah Nabi terakhir. Pada titik ini, komunitas Muslim awal perlu mengarang sebuah legenda suci,....

Keserupaan kisah Muhammad-Zayd dengan Dawud-Uriah dan kejanggalan urutan ayat-ayat dalam surah al-Ahazāb membuat Powers begitu yakin bahwa sosok Zayd adalah fiksi belaka. Untuk melengkapi analisanya, Powers mengajukan pembandingan terhadap kisah perang Mu'tah di mana Zayd terbunuh antara versi sejarawan Muslim dan non-Muslim. Yang ia perbandingkan adalah Kitāb al-Maghāzì karya al-Wāqidì dengan sebuah catatan biarawan Byzantium bernama Theophanes Confessor. Dua sumber tersebut memiliki kesamaan dalam menceritakan detil-detil perang seperti lokasi perang, jumlah pasukan Muslim yang pulang di bawah pimpinan seseorang bernama Khalid Ibn Walid, dan tentang kemenangan pasukan Byzantium atas kaum Muslimin pada perang tersebut ${ }^{48}$.

Di luar kesamaan-kesamaan tersebut, keduanya menyajikan informasi yang berbeda tentang jumlah komandan pasukan yang diutus Muhammad, nama komandan pasukan Byzantium, jumlah dua pasukan yang berhadap-hadapan, alasan kekalahan umat Islam serta jumlah orang Islam yang terbunuh. ${ }^{49}$ Namun, yang paling mengusik perhatian Powers adalah perbedaan dalam penentuan waktu terjadinya perang Mu'tah tersebut. Jika catatan Theopanes menyebutnya terjadi di awal pemerintahan Abū Bakr pada tahun $11 \mathrm{H}$, sumber-sumber tradisional Muslim justru meyebutnya terjadi pada tahun $7 \mathrm{H}$ atau 8

48 Powers, Muhammad Is Not the Father of Any of Your Men, 80-83.

49 Powers, 84. 
H. Perbedaan yang sangat mencolok ini membuat Powers berspekulasi bahwa para sejarawan Muslim sengaja memajukan waktu terjadinya perang Mu'tah untuk mengesankan seolah-olah Zayd meninggal sebelum Muhammad. ${ }^{50}$

Pembuktian yang dilakukan Powers dengan lebih mempercayai sumber non-Muslim jelas sekali merepresentasikan kelompok revisionis yang meyakini bahwa sumber-sumber tradisional Muslim memiliki masalah besar dalam hal otentisitas. Sirry sudah mengelaborasi panjang lebar hal ini dalam dua bukunya. Meski demikian, Sirry juga mengingatkan bahwa tidak ada alasan untuk menganggap sumbersumber dari luar tradisi Islam sebagai lebih reliabel daripada sumbersumber Islam sendiri, karena keduanya memiliki kompleksitasnya sendiri ${ }^{51}$. Namun yang jelas, Powers juga kesulitan merekonsiliasi kedua jenis sumber tersebut. Alih-alih mendapatkan gambaran yang lebih konkrit tentang perang Mu'tah, ia justru sampai pada spekulasi tentang kemungkinan dipalsukannya sejarah ini oleh sejarawan Muslim. Untuk memperkuat spekulasinya tersebut, Powers melakukan sebuah percobaan komparasi teks-teks samawi (intertekstualitas) yang ia terapkan untuk membaca al-Ahzzāb : 37.

Sebagaimana sudah disinggung sebelumnya, Powers meyakini ada kemiripan antara kisah Muhammad-Zaynab dengan kisah DawudBathsheba (II Samuel 11-12). Ia menambahkan lagi satu narasi Biblikal yang menurutnya sangat mirip dengan kisah Muhammad-Zaynab, yaitu kiah Yusuf-Maryam (Mathew 1: 18-25). Ringkasnya, cinta Yusuf kepada Maryam membuatnya menikahi Maryam. Naas, Maryam telah "disentuh" oleh utusan Tuhan yang membuatnya hamil. Menyadari pengantinnya telah berbadan dua, Yusuf ingin menceraikannya sebelum ia mendapatkan ilham dari Tuhan bahwa anak Maryam adalah ruh yang suci ${ }^{52}$. Menurut

50 Powers, 87-88.

51 Sirry, Kontroversi Islam Awal: Antara Madhhab Tradisionalis dan Revisionis, 54.

52 Powers, Muhammad Is Not the Father of Any of Your Men, 124-25. 
Powers, kisah Dawud-Bathheba dan Yusuf-Maryam adalah sumber utama (Powers menyebutnya sebagai Pre-texts) kisah Muhammad-Zaynab. Ketiganya menggambarkan hubungan yang tidak wajar antara laki-laki dan perempuan. Ketiganya mengandung unsur "kerahasiaan" karena Dawud menjaga rahasia atas apa yang ia lakukan kepada Bathsheba, Yusuf memiliki rencana rahasia terhadap Maryam dan Muhammad merahasiakan perasaanya terhadap Zaynab. Ketiga tokoh, lanjut Powers, juga khawatir dengan respon publik atas pernikahan yang mereka lakukan. Kesamaan ini membuat Powers berkesimpulan bahwa ketiga kisah yang masing-masingnya mewakili tradisi Yahudi, Kristen dan Islam tersebut mengandung alur yang sama dan menekankan pesan yang sama bahwa pada akhirnya, Tuhan telah menentukan sesuatu yang besar terjadi di akhir cerita: Dawud menyesal dan bertaubat, Maryam melahirkan Yesus dan Muhammad menjadi penutup para Nabi. ${ }^{53}$

Tidak cukup dengan menampilkan dua kisah yang menurutnya menjadi sumber kisah Muhammad-Zayd-Zaynab, Powers melangkah lebih jauh dengan mengkomparasikan antara sosok Zayd dalam tradisi Islam dengan sosok-sosok Biblikal lain seperti Yusuf, Eliezer Dammesek, Ishak, Ishmael, Uriah, Sulaiman, serta Ishak dari Aqedah. Metode pembandingan inilah yang Powers sebut sebagai intertextualitas. Dalam 25 halaman, Powers menyampaikan kemiripan antara sosok Zayd dengan figur-figur lain. Analisa Powers ini akan diringkas sebagai berikut:

\section{Tabel 2}

Intertektualitas: Perbandingan sosok Zayd dengan Figur-Figur Biblikal $^{54}$

53 Powers, 126.

54 Powers, $127-51$. 


\begin{tabular}{|l|l|}
\hline \multicolumn{1}{|c|}{ Figur } & \multicolumn{1}{|c|}{ Kesamaan Utama } \\
\hline \multirow{5}{*}{$\begin{array}{l}\text { Zayd dan } \\
\text { Yusuf }\end{array}$} & $\begin{array}{l}\text { Yusuf disifati Yefeh to'ar dan Zayd disebut ghuläm } \\
\text { yaf'a, keduanya berarti "yang tampan". Keduanya } \\
\text { pengembara, dibawa ke negeri antah-berantah } \\
\text { dan dijual. Keduanya menunjukkan kesetiaan } \\
\text { kepada tuan mereka (Yusuf ke Fir'aun dan Zayd } \\
\text { ke Muhammad), mendapatkan derajat yang } \\
\text { mulia (Yusuf sebagai Menteri dan Zayd sebagai } \\
\text { anak adopsi), dan menikah dengan perempuan } \\
\text { bangsawan. }\end{array}$ \\
\hline Zayd dan \\
Eliezer \\
Demmesek
\end{tabular}




\begin{tabular}{|l|l|}
\hline & $\begin{array}{l}\text { Setelah kelahiran Ishak, status Ishmael sebagai } \\
\text { pewaris Ibrahim dianulir sebagaimana status Zayd } \\
\text { dianulir oleh Muhammad. Ibrahim diceritakan } \\
\text { Zayd dan } \\
\text { Ishmael } \\
\text { pernah mengunjungi Ishmael untuk melihat } \\
\text { Muhammad. Baik Ibrahim maupun Muhammad } \\
\text { sama-sama masih mencintai Ishmael dan Zayd } \\
\text { meskipun status mereka telah dianulir. }\end{array}$ \\
\hline $\begin{array}{l}\text { Zayd dan } \\
\text { Uriah }\end{array}$ & $\begin{array}{l}\text { Istri Uriah dan istri Zayd sama-sama memukau } \\
\text { seorang Nabi (Dawud dan Muhammad) dan kedua } \\
\text { nabi tersebut khawatir dengan respon publik atas } \\
\text { apa yang terjadi. Zayd dan Uriah juga sama-sama } \\
\text { dikisahkan mati di medan perang. }\end{array}$ \\
\hline $\begin{array}{l}\text { Zayd dan } \\
\text { Sulaiman }\end{array}$ & $\begin{array}{l}\text { Keduanya memiliki dua nama, sama-sama } \\
\text { dikasihani Tuhan dan sama-sama pada awalnya } \\
\text { dipilih untuk melanjutkan misi kepemimpinan. }\end{array}$ \\
\hline
\end{tabular}

Pada intinya, Powers ingin mengatakan bahwa sosok Zayd yang tergambar dalam sejarah Islam adalah figur buatan yang kisahnya terinspirasi dari berbagai tokoh. Zayd adalah tokoh fiktif yang dibuat umat Islam generasi awal berdasarkan bacaan mereka atas tokoh-tokoh biblikal. Kisah masing-masing tokoh disarikan untuk membentuk seorang figur baru dengan satu tujuan, menguatkan klaim bahwa Muhammad adalah Nabi terakhir. ${ }^{55}$ Sampai di sini kita bisa melihat bahwa riset Powers sangat kompleks dan tentu saja penuh resiko bagi Powers sendiri untuk terjebak dalam hipotesa-hipotesa yang disampaikannya. Karenanya, riset yang dilakukan oleh Powers ini sangat sulit dilakukan oleh orang yang tidak memiliki "keragu-raguan" dalam dirinya. Secara khusus, Daniel Varisco mengakui bahwa metode intertektualitas Powers memang menghasilkan teori yang spekulatif dan, lebih penting lagi, sulit diterima oleh orang yang mempercayai

55 Powers, 150. 
bahwa al-Qur'an yang ada sekarang, kata demi katanya, adalah sama dengan wahyu yang diterima Muhammad, bukan berdasarkan kreasi umat Islam generasi awal, sebagaimana yang diyakini Powers. ${ }^{56}$

Metode perbandingan Powers yang 'nyentrik' ini juga mendapat perhatian dari Leor Halevi, sejarawan Islam dari Universitas Vanderbilt sekaligus penulis buku Muhammad's Grave: Death Rites and The Making of Islamic Society. Di satu sisi, dia mengapresiasi usaha Powers untuk mengkrontuksi Islam sebagai agama yang melanjutkan (continuing) agama-agama terdahulu, alih-alih menolaknya (overturning). Ia juga mengakui orisinalitas metodologi Powers yang menggambarkan pendekatan baru dalam filologi semitik, sejarah dan strukturalisme. Namun di sisi lain, Halevi merasa Powers belum bisa sampai pada kesimpulan yang valid dan meyakinkan, salah satunya karena terlalu klise jika Powers menggunakan dokumen sejarah di millennium kedua sebelum masehi ${ }^{57}$ untuk membaca sejarah di abad ke-7 Masehi. ${ }^{58}$

Dari sisi metodologi, sebenarnya komparasi Powers tidak benarbenar baru. Saleh menyebut sebuah karya yang ia duga menginspirasi Powers melakukan kajian yang serupa. Adalah Jon Levenson yang menulis buku berjudul The Death and The Resurrection of The Beloved Son: The Transformation of Child Sacrifice in Judaism and Christianity. Saleh memuji buku Levenson sebagai maha karya (masterpiece) dalam kajian literer terhadap kisah-kisah dalam Bibel di tradisi Yahudi dan Nasrani. Sementara Powers menurut Saleh, ingin mereplika karya Levenson dan menerapkannya dalam studi kesejarahan Islam. Secara khusus, Saleh mengkritik Powers tidak menyadari bahwa kajian intertekstualitas yang ia lakukan sangat absurd karena di akhir

56 Daniel Martin Varisco, "Review on Muhamad Is Not a Father of Any of Your Men: The Making on The Last Prophet," Middle East Studies Association of North America (MESA) 44, no. 1 (2010): 118.

57 Maksudya adalah kisah-kisah biblikal yang dipakai Powers sebagai perbandingan dengan kisah Zayd dalam tradisi Islam.

58 Leor Halevi, "Review on Muhammad Is Not The Father of Any of Your Men: The Making of The Last Prophet," The American Historical Review 116, no. 1 (2011): 247. 
analisis intertekstualnya, Zayd seperti menjadi setiap orang dan di saat yang sama tidak menjadi siapapun (he turns out to be everything and nothing). Zayd yang faktanya adalah satu-satunya sahabat yang namanya disebutkan dalam al-Qur'an, dirubah oleh Powers menjadi sosok fiktif lewat kajian kesejarahan yang tidak obyektif karena mengenyampingkan bukti-bukti primer dan bersandar pada buktibukti yang absurd..$^{59}$

\section{PALEOGRAFI DAN KODIKOLOGI: BIBLIOTHEQUE NATIONALE DE FRANCE, ARABE 328A}

Pada bagian ini, kerumitan riset Powers mencapai puncaknya. Lewat kajian terhadap kata kalālah dalam salah satu manuskrip alQur'an, ia bersikukuh bahwa dogma tertutupnya pintu kenabian benarbenar dibuat oleh umat Islam. Kata kalālah adalah dis legomenon, sebuah kata yang hanya muncul dua kali dalam al-Qur'an, keduanya di surah al-Nisā' (Ayat ke-12 dan 176). Sementara manuskrip yang memuat potongan ayat ini, pertama kali ditemukan pada Januari 1809 oleh Ulrich Seetzen dari Jerman ketika ia mengunjungi Masjid 'Amr Ibn 'As\} di Fustat, di mana seorang anak kecil mengajaknya untuk memasuki sebuah ruangan di sebelah utara masjid. Di dalam ruangan tersebut, terdapat manuskrip kuno yang ditumpuk di atas karpet, berserakan setebal kira-kira satu kaki, yang beberapa memuat tulisantulisan ayat al-Qur'an. Penemuan Seetzen ditindak lanjuti oleh Asselin de Cherville (1772-1822), seorang orientalis asal Perancis, hingga akhirnya manuskrip itu dipelajari dan diidentifikasi oleh Michele Amari (1806-89). Pada tahun 1998, F Deroche dan S. Noja Noseda menerbitkan edisi faksimil dari satu bendel manuskrip al-Qur'an tersebut dengan kode BNF 328a hingga bisa diakses secara luas. ${ }^{60}$

Tiga tahun kemudian, Y. Dutton meneliti BNF 328a dan menemukan beberapa poin penting bahwa BNF 328a kemungkinan ditulis pada tahun 50/60 H. Kodeks ini memuat tiga belas variasi huruf

59 Saleh, "Review Article," 263-64.

60 Powers, Muhammad Is Not the Father of Any of Your Men, 166-67. 
yang enam di antaranya diasosiasikan kepada bacaan Ibn 'Āmir (w. 118/736) dari Damaskus. Kodeks ini kental sekali nuansa Syria-nya dan sangat mungkin ditulis di Syiria atau Jazírah, bukan di Mesir, tempat ia ditemukan. Khusus pada manuskrip surah al-Nisāa, terdapat beberapa anomali yang dicatat Dutton sebagai "kesalahan penulisan" (scribal error), yaitu ditemukannya beberapa kata yang ditulis miring padahal secara umum tulisan dalam manuskrip ini berbentuk vertikal (tegak lurus). Telah teridentifikasi pula lewat bentuk tulisan bahwa BNF 328a ditulis oleh empat orang yang bekerja dalam satu tim. Dari 56 halaman, 47 halaman ditulis oleh penulis A (1a-9a, 10b-25a, 27b-28a, 30b-32a, 34b-35a dan 38b-56b), tujuh halaman oleh penulis B (28b-30a, 32b-34a, 35b-38a), satu halaman oleh penulis D (9b-10a) dan satu halaman oleh penulis E (25b-26a). Dari segi model tulisan, Deroche menggolongkan jenis tulisan BNF 328a sebagai Hijāzi 1, yaitu bentuk tulisan dengan huruf yang tipis dan ramping. ${ }^{61}$

Powers lalu membandingkan dua fargmen yang tertuliskan kata kalālah di dalamnya. Pada fragmen pertama yang memuat potongan Q. 4: 176, Powers menyimpulkan bahwa penulisan kata kalālah-nya biasa saja dan tidak problematis. Sementara pada fragmen kedua yang bertuliskan Q. 4: 12, Powers menemukan sesuatu yang janggal.

\section{Gambar 1}

Potongan Q. 4: 176 dalam BNF Arabe 328a, folio $20 b^{62}$

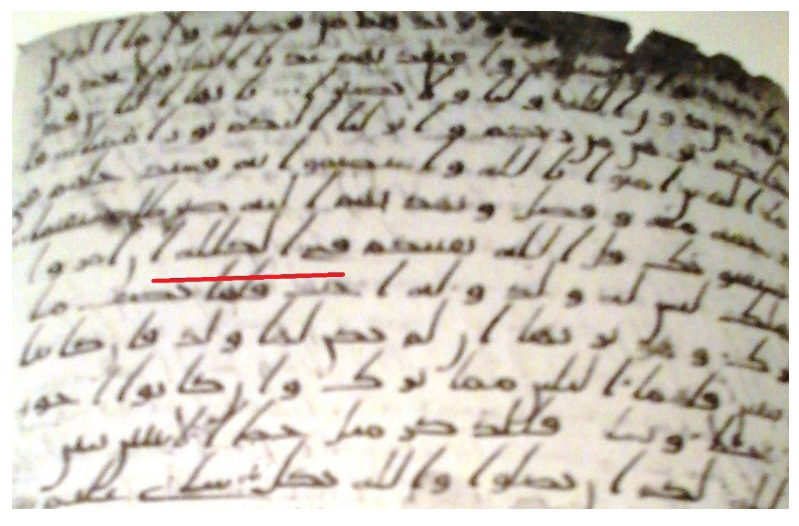

61 Powers, 168.

62 Powers, 170. 


\section{Gambar 2.}

Potongan Q. 4: 12 dalam BNF Arabe 328a, folio $10 b^{63}$

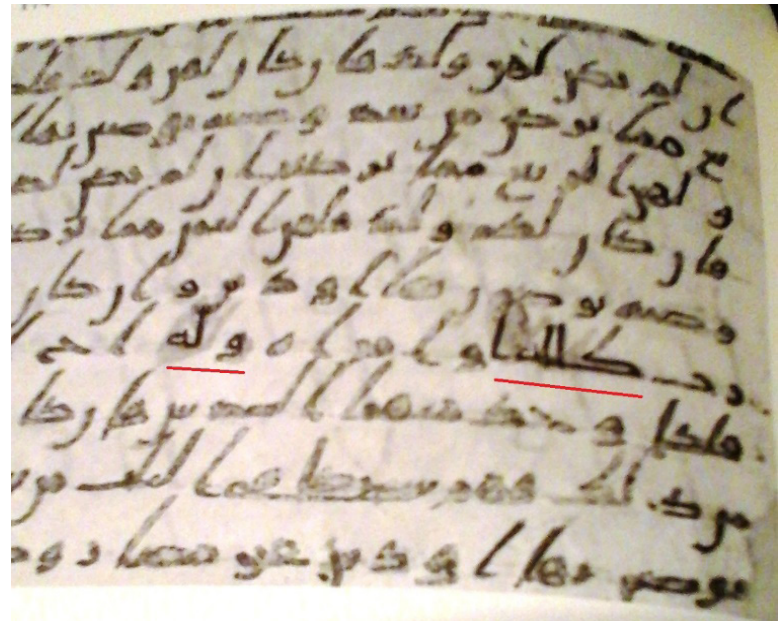

Dalam kodeks tersebut, tertuliskan fragmen dari al-Nisā': 12,

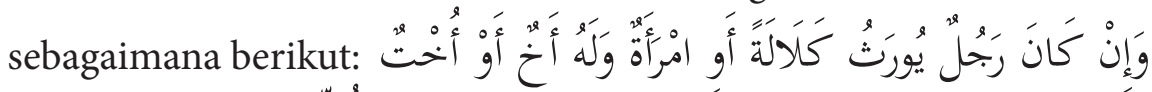

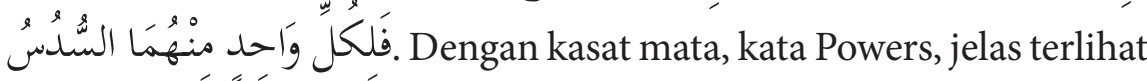
sesuatu yang menarik pada penulisan kata kalālah di atas. Sebagaimana folio 20b, folio $10 \mathrm{~b}$ ditulis oleh penulis A. Tapi, tulisan tersebut nampaknya telah dikoreksi, tepatnya dua kali. Sekali oleh penulis A sendiri, dan sekali oleh orang lain yang oleh Powers disebut 'korektor 2'. Dengan bantuan sinar ultra-violet, Powers menemukan bahwa korektor 2 menuliskan sesuatu yang berbeda kemiringannya dari versi asli yang vertikal. Korektor 2 juga memakai jenis tinta (carbonbased) yang berbeda dengan tinta pada tulisan aslinya (metallo-galic) dan memakai jenis huruf yang berbeda pula. Tulisan tangan korektor 2 ini disebut oleh Deroche sebagai Abbasid book hand yang sering digunakan pada abad ke-3 H. Dengan demikian, jarak antara tulisan asli oleh penulis A dengan koreksi dari korektor 2 berkisar dua abad ${ }^{64}$.

63 Powers, 174.

64 Powers, 171. 
Yang ingin disampaikan oleh Powers adalah bahwa Q. 4: 12 yang ada dalam al-Qur'an dewasa ini telah dirubah dan disesuaikan. Ia

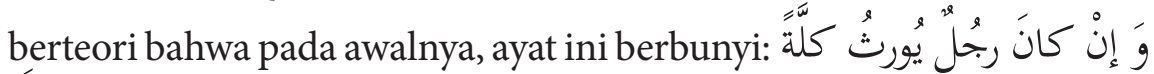
(dan jika ada seorang laki-laki yang mati meninggalkan seorang anaḱ tiri perempuan atau seorang istri), kemudian direvisi menjadi: كانَ رجُل يُورَثُ كَلَالَةً أو امرأَة mati dengan tidak meninggalkan anak atau ayah). ${ }^{65}$ Powers berhipotesa bahwa kata kallah dalam al-Nisā': 12 telah diganti dengan kata kalālah yang merupakan kata baru dalam bahasa Arab. Lalu, satu setengah abad kemudian, al-Nisā': 176 ditambahkan ke dalam al-Qur'an. ${ }^{66}$ Teori Powers ini menyisakan pertanyaan mengenai arti dari kata kallah. Powers lantas melakukan pelacakan sederhana terhadap bahasa-bahasa semitik lain yang masih satu rumpun dengan Bahasa Arab, yaitu Bahasa Akkadia, Ugaritik, Ibrani, Aramaik, Syriak, Arab Selatan dan Ethiopia. Dari pelacakan ini, Powers menemukan kemiripan untuk kata kallah yang berarti 'anak perempuan tiri' dalam bahasa-bahasa semitik, dan tidak menemukan apa-apa untuk kata kala>lah yang sering diartikan 'orang yang tidak memiliki ayah ataupun anak'. Ia sampai pada kesimpulan bahwa pada masa Muhammad, istilah kallah masih dipakai secara luas sementara istilah khilāfah belum ada ${ }^{67}$

Firestone membantu kita memahami implikasi dari teori Powers ini. Powers berkeyakinan bahwa kata kallah dan imra'ah merujuk pada figur yang sama, yaitu Zaynab Bintu Jah\}sh, istri Muhammad yang dulunya adalah istri Zayd, anak angkatnya. Pemberian warisan kepada Zaynab adalah pengakuan atas kedudukannya, sehingga setiap anak yang lahir darinya, baik dengan Zayd maupun Muhammad akan

65 Powers, 177.

66 Madelung, "Review on Muhammad Is Not the Father of Any of Your Men: The Making of The Last Prophet (Divinations: Rereading Late Ancient Religion),” 729.

67 Powers, Muhammad Is Not the Father of Any of Your Men, 180. 
meneruskan tahta kepemimpinan. ${ }^{68}$ Lebih lanjut, revisi ini menurut Powers dipengaruhi oleh kondisi politik yang ingin memantapkan doktrin teologis tentang finalitas kenabian. Kesimpulan Powers ini dikuatkan dengan sebuah logika yang "cantik". Powers mengutip beberapa riwayat yang dinisbahkan kepada 'Umar Ibn al-Khațāa yang mengatakan bahwa khiläfah adalah satu dari tiga hal yang belum dijelaskan oleh Nabi Muhammad semasa hidupnya. Ada juga riwayat tentang 'Umar yang menjelang wafat berwasiat kepada Ibn 'Abbās bahwa ada dua perkara yang harus Ibn 'Abbās ingat, yaitu bahwa 'Umar tidak memilih penerusnya (lam astakhlif) dan 'Umar tidak membuat keputusan apapun tentang khiläfah. Menurut Powers, bukanlah kebetulan, khilāfah disebut bersamaan dengan kalālah. Dengan kata lain, khiläfah berhubungan dengan politik suksesi kepemimpinan. ${ }^{69}$

Gagasan sensasional Powers lewat kajian manuskrip al-Qur'an ini juga menuai kontroversi. Ada yang menagapresiasi, ada pula yang menemukan kesalahan fatal di balik argumentasi yang disusun oleh Powers. Hawting misalnya menyebut paparan ala detektif Powers cukup meyakinkan meskipun masih terbuka untuk diperdebatkan ${ }^{70}$. Bagaimanapun juga dengan teori tersebut, Powers berkewajiban untuk menjelaskan mengapa kata kallah tidak pernah muncul dalam sumber-sumber tradisional. Pertanyaan ini belum terselesaikan oleh Powers. Keraguan yang sama juga diutarakan oleh Firestone mengenai sulitnya Powers menjelaskan mengapa kata tersebut seakan tiba-tiba menghilang dari peradaban Arab abad ke-7. Bahkan jika kata ini -sebagaimana diasumsikan Powers- dipakai pada generasi yang sangat awal, Powers belum menjelaskan mengapa kata tersebut tiba-tiba muncul dalam al-Qur'an. ${ }^{71}$ Kritik serupa juga disampaikan oleh Saleh

68 Firestone, "Review on Muhammad Is Not The Father of Any of Your Men," 180.

69 Powers, Muhammad Is Not the Father of Any of Your Men, 224.

70 Hawting, "Review on Muhammad Is Not The Father of Any of Your Men: The Making of

The Last Prophet," 118-19.

71 Firestone, "Review on Muhammad Is Not The Father of Any of Your Men," 181. 
yang menganggap Powers mengandaikan sebuah amnesia leksikografik massal dengan teorinya tersebut. Hal yang menurut Saleh sangat absurd. ${ }^{72}$ Yang lebih fatal dari itu semua adalah teori Powers bahwa kata kalālah baru diciptakan pada abad pertama Hijriyah bersamaan dengan revisi terhadap al-Ahzāb: 12. Merujuk pada karya A. Cilardo tentang kata kalalah (dipublikasikan pada 2005), sulit untuk dibantah bahwa kata kalalah sudah dipakai pada puisi dan karya sastra di masa jāhiliyyah sebelum Islam muncul ${ }^{73}$.

Dari sisi rekonstruksi kodikologis, adalah Walid Saleh yang mengusulkan cara pembacaan yang berbeda terhadap koreksi pada manuskrip dari apa yang diteorisasikan oleh Powers. Menurut Saleh, fenomena ini termasuk haplografi, yaitu penghilangan satu atau beberapa huruf yang harusnya ditulis beberapa kali secara tidak sengaja. Sederhananya dalam kasus koreksi kata kalälah, seorang penulis naskah membuat kesalahan haplografik dalam menuliskan sesuatu lalu dia mengoreksi tulisannya tersebut. Saleh lantas mengutip penjelasan Adam Gacek, salah seorang ahli manuskrip Arab, yang menyebutkan bahwa haplografi adalah satu dari sekian kesalahan yang sering terjadi dalam penulisan naskah $\mathrm{Arab}^{74}$.

Saleh juga mempermasalahkan logika Powers yang serta-merta mengganggap kata kalalah sengaja dibuat belakangan oleh sebuah konspirasi tertentu hanya karena Powers tidak bisa melacak akar kata kalalah dalam bahasa-bahasa semitik. Menurut Saleh, bahasa Arab adalah bahasa semitik dengan perbendaharaan kata terkaya ${ }^{75}$. Dalam bantahannya terhadap Powers dan revisionis secara umum, Saleh menyebut kelompok ini lebih condong pada kecerdasan retorik (rhetoric artifice) alih-alih pada analisis yang koheren yang

72 Saleh, "Review Article," 255.

73 Robinson, "Review on Muhammad Is Not The Father of Any of Your Men: The Making of

The Last Prophet: Divinations: Rereading Late Antiquity Religion by David Powers," 172.

74 Saleh, "Review Article," 252-53.

75 Powers, Muhammad Is Not the Father of Any of Your Men, 255. 
berdasarkan bukti-bukti. Ia bahkan menyebut atraksi kelompok ini mulai menjadi seperti pertunjukan komedi (a farce) yang dipenuhi dengan kesembronoan. ${ }^{76}$

\section{KESIMPULAN}

Inti buku Powers adalah bahwa doktrin 'Muhammad sebagai penutup para Nabi' sengaja dimunculkan dalam konstruksi salvation history. Tidak main-main, Powers menawarkan revisi sejarah Islam khususnya yang berkaitan dengan penerus kenabian Muhammad berdasarkan asumsinya bahwa terdapat motif warisan dalam status kenabian dalam Islam sebagaimana dalam tradisi Yahudi dan Nasrani. Untuk membuktikan klaimnya tersebut, Powers meyakini dua hal: (1) bahwa kisah Zayd sengaja diciptakan, dan bahwa (2) sedikit revisi telah ditambahkan pada teks al-Qur'an.

Metodologi pembuktian Powers terhadap point pertama sangat berdasar pada apa yang disebutnya dengan intertekstualitas, yaitu perbandingan antara teks-teks dalam tradisi Islam dengan tradisi dua agama semitik sebelumnya. Lewat komparasi ini Powers menyimpulkan bahwa kisah Muhammad-Zayd-Zaynab terinspirasi dari kisah DawudUriah-Bathsheba dan kisah Yusuf-Maryam. Powers juga meyakini bahwa sosok Zayd terinspirasi dari figur-figur Biblikal seperti Yusuf, Eliezer Dammesek, Ishak, Ishmael, Uriah da Sulaiman. Sementara terhadap teks al-Qur'an tentang Zayd, Powers menawarkan pembacaan ulang secara kronologis. Powers juga mengajukan pembandingan terhadap kisah perang Mu'tah di mana Zayd terbunuh antara versi sejarawan Muslim dan non-Muslim yang membuatnya berspekulasi bahwa para sejarawan Muslim sengaja memajukan waktu terjadinya perang Mu'tah untuk mengesankan seolah-olah Zayd meninggal sebelum Muhammad.

76 Saleh, “Review Article," 251. 
Sedangkan pembuktian poin kedua dilakukan oleh Powers dengan mengkaji kata kalālah dalam BNF 328a. Ia meyakini bahwa Q. 4: 12 yang ada dalam al-Qur'an dewasa ini telah dirubah dan disesuaikan. Powers lantas melakukan pelacakan sederhana terhadap bahasabahasa semitik lain yang masih satu rumpun dengan bahasa Arab untuk melihat makna kata kallah dan kalālah. Metodologi Powers di atas termasuk cara dia membuat hipotesa dan argumen dan memperlakukan sumber-sumber Islam tradisonal merepresentasikan sepenuhnya kesarjanaan revisionis radikal.

Artikel ini menunjukkan bahwa dalam asumsinya yang paling mendasar sekalipun, karya Powers mendapat tanggapan kritis dari para sejarawan modern. Beberapa catatan metodologis mendasar adalah: (1) asumsi dasar Powers tentang "genealogi kenabian" dan "doktrin tertutupnya pintu kenabian dalam Islam" muncul dari keyakinannya tentang adanya pola khas yang sama di antara agamaagama samawi. Usahanya untuk menemukan pola khas ini menjadikan Powers apatis terhadap reliabilitas sumber Islam tradisional dan secara membabi buta menganggap semuanya fiksi dan fabula; (2) Percobaan intertekstualisasi yang dilakukan Powers terlalu absurd dan tidak apple to apple karena menggunakan dokumen sejarah di millenium kedua sebelum masehi untuk membaca sejarah di abad ke-7 Masehi; (3) rekonstruksi kodikologis Powers terhadap kata kallah vis a vis kalālah, meskipun dilakukan dengan cukup hati-hati, namun gagal menjelaskan logika kebahasaan di balik amnesia leksikografik massal terhadap kata pertama dan muncul dengan tiba-tibanya kata kedua. Powers juga mengenyampingkan temuan lain bahwa kata kalālah sudah dipakai sejak zaman Pra-Islam dan bahwa perbaikan manuskrip al-Qur'an yang ia temukan semata-mata hanyalah sejenis haplografi saja. 


\section{DAFTAR PUSTAKA}

Amir-Moezzi, Mohammad Ali, Etan Kohlberg, Ḥasan Anșārī, and Eric Ormsby. The Silent Qur'an \& the Speaking Qur'an: Scriptural Sources of Islam between History and Fervor. New York: Columbia University Press, 2016.

Crone, Patricia, and Michael Cook. Hagarism: The Making of Islamic World. Cambridge: Cambridge University Press, 1977.

Evstatiev, Simeon. "On The Perception of the Kha $>$ tam Al-Nabiyyi $>n$, Doctrine in Arabic Historical Thought: Confirmation or Finality." In Studies in Arabic and Islam (Proceedings of the 19th Congress, Union Europeenne Des Arabisants et Islamisants, Halle, 1998), 455-67. Leuven: UITGEVERIJ PEETERS, 2002.

Firestone, Reuven. "Review on Muhammad Is Not The Father of Any of Your Men." International Journal of Middle East Studies 44, no. 1 (2012): 179-81.

Friedmann, Yohanan. "Finality of Prophethood in Sunni Islam." Jerusalem Studies in Arabic and Islam 7 (1986): 177-215.

-_- Prophecy Continues: Aspects of Ahmadi Religions Thought and Its Medieval Background. Berkeley: University of California Press, 1989.

Halevi, Leor. "Review on Muhammad Is Not The Father of Any of Your Men: The Making of The Last Prophet." The American Historical Review 116, no. 1 (2011): 246-47.

Hawting, G.R. "Review on Muhammad Is Not The Father of Any of Your Men: The Making of The Last Prophet." Brill, Islamic Law and Society 18, no. 1 (2011): 116-19.

Ibn Sulaimān, Muqātil. Tafsīir Muqātil Ibn Sulaimān. Edited by 'Abdullāh Mạ̣mūd Shaḥḥ̄âtah. Vol. 3. 5 vols. al-Hay'ah al-Miṣ riyyah al-' Āmmah, 1979. 
Jābirī, Muḥammad 'Ābid al-. Fahm al-Qur'ān al-ḥakìm: at-tafsìr alwādihh hasab tartīb an-nuzūl. Qism 3: [...]. Ṭab'a 1. Bairūt: Markaz Dirāsāt al-Waḥda al-'Arabīya, 2009.

Madelung, Wilfred. "Review on Muhammad Is Not the Father of Any of Your Men: The Making of The Last Prophet (Divinations: Rereading Late Ancient Religion)." The University of Chicao Press on Behalf of The Medieval Academy of America 85, no. 3 (2010): 727-29.

Noldeke, Theodor, Friedrich Schwally, Bergsträsser, and O. Pretzl. The History of The Quran. Translated by Wolfgang Behn. Leiden, 2013.

Powers, David Stephan. Muhammad Is Not the Father of Any of Your Men: The Making of the Last Prophet. Divinations. Philadelphia: University of Pennsylvania Press, 2009.

Robinson, Chase F. "Review on Muhammad Is Not The Father of Any of Your Men: The Making of The Last Prophet: Divinations: Rereading Late Antiquity Religion by David Powers." Journal of the American Oriental Society 131, no. 1 (2011): 171-73.

Saleh, Walid A. "Review Article: Muhammad Is Not the Father of Any of Your Men: The Making of the Last Prophet, by David S. Powers. University of Pennsylvania Press, 2009. 376 Pp., 7 Illus. $\mathrm{Hb} \$ 55.00 / £ 36.00$. ISBN-13: 9780812241785 .” Comparative Islamic Studies 6, no. 6.1-6.2 (December 29, 2011). https://doi.org/10.1558/ cis.v6i1-2.251.

Sirry, Mun'im. Kemunculan Islam Dalam Kesarjanan Revisionis. Yogyakarta: Suka Press, 2017.

- - . Kontroversi Islam Awal: Antara Madhhab Tradisionalis dan Revisionis. Bandung: Mizan, 2015.

Varisco, Daniel Martin. "Review on Muhamad Is Not a Father of Any of Your Men: The Making on The Last Prophet." Middle East Studies Association of North America (MESA) 44, no. 1 (2010): 117-18. 
Wansbrough, John. Qur'anic Studies: Sources and Methods of Scriptural Interpretation. Oxford: Oxford University Press, 1977.

- - . The Sectarian Milieu: Content and Composition of Islamic Salvation History. Oxford: Oxford University Press, 1978. 
